\title{
Korelasi Perubahan Tekanan Darah dengan Perubahan Kadar Kolesterol Total Pasien Prolanis yang Mendapatkan Jus Lidah Buaya (Aloe vera)
}

\author{
Yuliawati $\mathrm{V}^{1}$, Vani $\mathrm{AT}^{2}$, Heppy $\mathrm{F}^{3}$ \\ ${ }^{1}$ Mahasiswa Fakultas Kedokteran Universitas Baiturrahmah \\ email: yuliawativina@yahoo.co.id \\ ${ }^{2}$ Bagian Histologi, Fakultas Kedokteran Universitas Baiturrahmah Padang, Indonesia \\ ${ }^{3}$ Bagian Penyakit Dalam, Fakultas Kedokteran Universitas Baiturrahmah Padang, Indonesia
}

\begin{abstract}
Abstrak
Pendahuluan: Salah satu faktor dari hipertensi adalah hiperkolesterolemia. Upaya menurunkan kadar kolesterol dalam darah selain dapat dilakukan dengan mengonsumsi obat, juga dapat dilakukan dengan perubahan pola hidup yang sehat dan diet. Diet merupakan cara yang efektif untuk menurunkan kadar kolesterol dalam darah. Salah satu bahan makanan yang memiliki manfaat anti hiperkolesterolemia adalah lidah buaya (Aloe vera). Tujuan: Untuk mengetahui hubungan perubahan kadar kolesterol darah terhadap perubahan tekanan darah pada pasien prolanis dengan gangguan kolesterol yang mendapatkan jus aloe vera di Puskesmas Air Dingin tahun 2018. Metode: Penelitian ini dilakukan pada pasien prolanis yang dilaksanakan pada bulan Juli-Agustus tahun 2018 di Puskesmas Air Dingin. Desain penelitian adalah penelitian analitik dengan pendekatan cross-sectional. Populasi terjangkau dalam penelitian ini adalah semua pasien prolanis Puskesmas Air Dingin tahun 2018 dengan 15 sampel menggunakan teknik simple random sampling. Analisa Data disajikan dalam mean \pm SD bila data terdistribusi normal. Bila tidak normal, sajikan dalam median (min-max). Hasil: Tekanan darah sistolik sebelum dan sesudah mengkonsumsi Jus Aloe vera diperoleh rata-rata 137,26 mmHg dan 119,86 mmHg. Tekanan darah diastolik sebelum dan sesudah mengkonsumsi Jus Aloe vera diperoleh rata-rata $86,13 \mathrm{mmHg}$ dan $77,80 \mathrm{mmHg}$. Jumlah kolesterol sebelum dan sesudah mengkonsumsi Jus Aloe vera diperoleh rata-rata 264,93 dan 240,36. Tekanan darah sistolik diperoleh nilai $r=0,875$ kategori sangat kuat, nilai $p=0,000(p<0,05)$ dan pada tekanan darah diastolik diperoleh nilai $r=0,631$ kategori kuat, nilai $p=0,012(p<0,05)$, maka terdapat hubungan perubahan tekanan darah dengan perubahan kadar kolesterol total pada pasien prolanis dengan gangguan kolesterol yang mendapatkan jus aloe vera di Puskesmas Air Dingin tahun 2018. Kesimpulan: Terdapat hubungan perubahan tekanan darah dengan perubahan kadar kolesterol total pada pasien prolanis dengan gangguan kolesterol yang mendapatkan jus aloe vera di Puskesmas Air Dingin tahun 2018.
\end{abstract}

Kata Kunci: Tekanan Darah, Kadar Kolesterol, Jus Aloe Vera

\begin{abstract}
Introduction: One factor of hypertension is hypercholesterolemia. Efforts to lower cholesterol levels in the blood beside taking the medicine, can also with a healthy lifestyle change and diet. Diet is an effective way to lower cholesterol levels in the blood. One of the ingredients that has the benefits of anti-hypercholesterolemia is Aloe vera. Aims: Knowing the correlation between changed blood pressure and changed the Total cholesterol for Prolanis patients with cholesterol disorder that get Aloe vera juice in the Padang Air Dingin Health Center in 2018. Method: This study was conducted on the Prolanis patient in the Padang Air Dngin Helth Center conducted from July - August 2018. The type of research used was a colerative analytic analytic with cross sectional study design. The affordable population are all prolanis patient in the Padang Air Dingin Health Center with 15 samples using simple random sampling technique. Univariate data analysis presented in the form of the average, standard deviation, minimum, maximum, and bivariates analyses using the Spearman rho test, using the SPSS program. Result: Systolic blood pressure before and after consuming Aloe vera juice obtained on average $137.26 \mathrm{mmHg}$ and $119.86 \mathrm{mmHg}$. Diastolic blood pressure before and after consuming Aloe vera juice was obtained on average $86.13 \mathrm{mmHg}$ and $77.80 \mathrm{mmHg}$. The amount of cholesterol before and after consuming Aloe vera juice was obtained on average 264.93 and 240.36. Systolic blood pressure obtained $r$
\end{abstract}


52 Heme, Vol III No 1

January 2021

$=0.875$ values (very strong categories), the value $P=0,000(P<0.05)$ and at the diastolic blood pressure obtained $r=0.631$ values (strong categories), Value $P=0,012(P<0.05)$. Conclusion: there is a correlation betweeen changed blood pressure and changed the total cholesterol for patients with cholesterol disorder (hypercholesterolemia) that get aloe vera juice in the Padang Air Dingin Health Center in 2018.

Keywords: Blood pressure, Cholesterol levels, Aloe vera juice.

Email : heme@unbrah.ac.id 


\section{Pendahuluan}

Program Pengelolaan Penyakit Kronis (Prolanis) adalah suatu sistem pelayanan kesehatan yang melibatkan peserta, fasilitas kesehatan dan BPJS Kesehatan dalam rangka pemeliharaan kesehatan bagi peserta BPJS Kesehatan yang menderita penyakit kronis untuk mencapai kualitas hidup yang optimal dengan biaya yang efektif dan efisien. Prolanis bertujuan untuk mendorong peserta penyakit kronis seperti hipertensi dan diabetes melitus tipe 2 mencapai kualitas hidup yang optimal sehingga dapat mencegah timbulnya komplikasi penyakit. Apabila penyakit sindrom metabolik seperti hipertensi dan diabetes melitus tipe 2 tidak dikelola dengan baik akan menimbulkan penyakit lanjutan seperti jantung, stroke, dan gagal ginjal. ${ }^{1}$

Prevalensi sindrom metabolik di Indonesia tahun 2018 sebanyak 21,66\% dan di Sumatra Barat $29.85 \%$. $^{2}$ Peningkatan tekanan darah adalah salah satu sindrom metabolik yang terus meningkat sejalan dengan perubahan gaya hidup seperti merokok, inaktifitas fisik dan stres psikososial. ${ }^{3}$ Data World Health Organization (WHO) tahun 2015 menunjukkan 1 dari 3 orang di dunia terdiagnosis hipertensi. ${ }^{4}$ Berdasarkan Riset kesehatan dasar 2018 prevalensi hipertensi di Indonesia adalah sebesar 34,1\%. ${ }^{4}$ Prevalensi hipertensi di Sumatra Barat tahun 2017 sebesar 23\%.5 Berdasarkan data Dinas Kesehatan Kota Padang tahun 2018 prevalensi hipertensi sebesar $71 \% .^{6}$

Salah satu faktor resiko dari hipertensi adalah hiperkolesterolemia. Hiperkolesterolemia merupakan suatu kondisi dimana kolesterol dalam darah meningkat melebihi ambang normal yang ditandai dengan meningkatnya kadar kolesterol total terutama Low Density Lipoprotein (LDL) dan diikuti dengan penurunan kadar High Density Lipoprotein (HDL) darah. Peningkatan kadar kolesterol total akan mengakibatkan peningkatan angka kejadian terjadinya hipertensi. $^{7}$

Penelitian oleh Rahmat Feryadi, dkk di Kota Padang pada tahun 2012 menyatakan bahwa terdapat hubungan kadar kolesterol dengan kejadian hipertensi dengan nilai $\mathrm{p}=0,04$ $(\mathrm{p}<0,05) .{ }^{8}$ Penelitian lainnya oleh Maulana tahun 2007 menyatakan terdapat hubungan bermakna antara kadar kolesterol total dan hipertensi (nilai $\mathrm{p}=0,002$ ). ${ }^{9}$ Kolesterol dalam kondisi normal tidak menimbulkan dampak buruk, termasuk sebagai pemicu kenaikan tekanan darah, namun jika teroksidasi maka LDL akan meningkat dan menumpuk dibagian dinding arteri yang akan mempersempit dan menyumbat arteri dan membuat tekanan darah di arteri meningkat. ${ }^{10}$

Upaya menurunkan kadar kolesterol dalam darah selain dapat dilakukan dengan mengonsumsi obat, juga dapat dilakukan dengan perubahan pola hidup yang sehat dan diet. Diet merupakan cara yang efektif untuk menurunkan kadar kolesterol dalam darah. Salah satu bahan makanan yang memiliki manfaat anti hiperkolesterolemia adalah lidah buaya (Aloe vera). Kandungan lidah buaya yang berfungsi sebagai anti kolesterol adalah glukomanan, anthraquinones, asam folat, enzim lipase, lignin, vitamin B3 dan vitamin C. ${ }^{11}$ Anthraquinones mempercepat transport makanan di usus dan menghambat penyerapan kolesterol. ${ }^{12}$ Vitamin B3 (asam nikotinat) yang mampu menghambat produksi VLDL yang akan menurunkan kadar LDL. ${ }^{12}$ Vitamin $\mathrm{C}$ yang mempunyai efek membantu reaksi hidroksilasi dalam pembentukan asam empedu sehingga meningkatkan produksi garam empedu yang berakibat meningkatnya ekskresi kolesterol. $^{12}$

Beberapa penelitian telah mengamati efek lidah buaya terhadap kolesterol. Subbiah Rajasekaran dkk di India menunjukan bahwa aloe vera dapat menurunkan profil lipid dalam darah dan menurunkan kadar glukosa dalam darah secara signifikan. ${ }^{11}$ Sianipar tahun 2012 menyatakan terjadi penurunan 
signifikan kadar LDL dan peningkatan signifikan kadar HDL dengan pemberian jus lidah buaya selama 14 hari pada wanita dislipidemia. ${ }^{11}$ Hermawan menyatakan pemberian jus lidah buaya dengan dosis $3 \mathrm{ml} / 200 \mathrm{grBB} /$ hari selama 4 minggu pada tikus yang diberikan diet tinggi kolesterol dapat meningkatkan kadar kolesterol HDL secara bermakna. ${ }^{11}$

\section{Metode Penelitian}

Ruang lingkup penelitian ini adalah pasien prolanis di Puskesmas Air Dingin pada bulan Juli - Agustus 2018. Penelitian ini dilaksanakan pada bulan Juli - Agustus tahun 2018 di Puskesmas Air Dingin, kecamatan Koto tangah, Padang, Sumatra Barat. Jenis penelitian yang digunakan adalah studi analitik koleratif dengan rancangan penelitian cross sectional.

\section{A. Cara KerJa}

1. Pemilihan subjek dilakukan dengan mengumpulkan semua prolanis Puskesmas Air Dingin pada bulan Juli Agustus 2018.

2. Melakukan pengamatan yang difokuskan pada kadar total kolesterol dan tekanan darah.

3. Prolanis yang berpuasa \pm 12 jam sebelumnya diminta untuk menandatangani informed consent sebagai persetujuan untuk dilakukan pengambilan darah.

4. Pengambilan darah dilakukan di vena mediana cubitii yang telah dibersihkan menggunakan kapas alkohol $70 \%$. Kemudian lengan atas dipasang tourniquet dan diminta untuk mengepalkan tangan.

5. Kemudian dilakukan proses pengambilan darah dengan spuit dan tabung darah yang telah disiapkan oleh pihak lab.

6. Letakkan kembali kapas alkohol tadi untuk melepaskan spuit dan tarik secara perlahan.

7. Darah yang ada didalam tabung diberi identitas responden. Kemudian sampel darah dibawa ke Lab Pramita untuk mengetahui nilai total kolesterol responden.

\section{B. Analisa data}

Data diolah dan dianalisis dengan menggunakan analisis univariat dan bivariat. Analisi univariat dilakukan untuk menghasilkan persentase dari tiap variabel dan analisis bivariat dilakukan terhadap dua variabel yang diduga mempunyai hubungan atau korelasi. Analisis akan dilakukan dengan menggunakan analisa korelasi Spearman. Bila nilai sig. $<0,05$ maka data dinyatakan bermakna (signifikan) dan hipotesa $\mathrm{H}_{1}$ akan diterima.

\section{Hasil Penelitian}

Penelitian ini bertujuan untuk mengetahui korelasi perubahan tekanan darah dengan perubahan kadar total kolesterol pada pasien prolanis dengan gangguan kolesterol yang mendapatkan jus aloe vera di puskesmas Air Dingin tahun 2018 yang dilakukan pada semua pasien prolanis di puskesmas Air Dingin sampel penelitian yang telah memenuhi kriteria inklusi dan esklusi. Berdasarkan hasil pengumpulan dan analisa terhadap data yang telah didapat, maka penulis mendapatkan kesimpulan hasil penelitian dalam paparan dibawah ini.

\section{A. Analisa Univariat}

\section{Tekanan Darah Sistolik Pasien HiPERKOLESTEROLEMIA SEBELUM Dan Sesudah Mengkonsumsi JuS ALOE VERA}

Berdasarkan penelitian yang dilakukan, diperoleh deskriptif tekanan darah sistolik pasien sebelum dan sesudah mengkonsumsi Jus Aloe vera seperti pada tabel berikut:

Tabel 1. Distribusi Frekuensi Tekanan Darah Sistolik SEbelum daN SESUdah Mengkonsumsi Jus aloe Vera di Puskesmas AIR Dingin TAHUn 2018

\begin{tabular}{lcccc}
\hline $\begin{array}{l}\text { Tekanan } \\
\text { Darah }\end{array}$ & Mean & $\begin{array}{c}\text { Std. } \\
\text { Deviasi }\end{array}$ & Min & Maks \\
\hline Sebelum & 137,26 & 14,601 & 110 & 157
\end{tabular}




\begin{tabular}{lcccc} 
Sesudah & 119,86 & 12,368 & 100 & 139 \\
$\alpha$ & 17,4 & 2,233 & 10 & 18 \\
\hline
\end{tabular}

Berdasarkan tabel 1 diperoleh hasil tekanan darah sistolik sebelum mengkonsumsi Jus Aloe vera diperoleh rata-rata $137,26 \mathrm{mmHg}$ dengan standart deviasi 14,601, tekanan darah minimum $110 \mathrm{mmHg}$ dan maksimum $157 \mathrm{mmHg}$. Tekanan darah sistolik sesudah mengkonsumsi Jus Aloe vera adalah 119,86 dengan standart deviasi 12,368, tekanan darah terendah $100 \mathrm{mmHg}$ dan tertinggi 130 $\mathrm{mmHg}$.

\section{Tekanan Darah Diastolik Pasien HIPER-KOLESTEROLEMIA SEBELUM DAN SESUdAh Mengkonsumsi JuS LIDAH BUAYA ALOE VERA}

Berdasarkan penelitian yang dilakukan, diperoleh deskriptif tekanan darah diastolic pasien sebelum dan sesudah mengkonsumsi Jus Aloe vera seperti pada tabel berikut:

TABel 2. Distribusi Frekuensi TEKANAN DARAH Diastolik SEbElum DAN SESUdAH Mengkonsumsi Jus aloe Vera di Puskesmas Air Dingin TAHUn 2018

\begin{tabular}{lcccc}
\hline $\begin{array}{c}\text { Tekanan } \\
\text { Darah }\end{array}$ & Mean & $\begin{array}{c}\text { Std. } \\
\text { Deviasi }\end{array}$ & Min & Maks \\
\hline Sebelum & 86,13 & 7,482 & 74 & 100 \\
Sesudah & 77,80 & 7,143 & 66 & 90 \\
$\alpha$ & 8,33 & 0,339 & 8 & 10 \\
\hline
\end{tabular}

Berdasarkan tabel 2 diperoleh hasil tekanan darah diastolik sebelum mengkonsumsi Jus Aloe vera diperoleh rata-rata $86,13 \mathrm{mmHg}$ dengan standart deviasi 7,482, tekanan darah minimum $74 \mathrm{mmHg}$ dan maksimum 100 mmHg. Tekanan darah diastolik sesudah mengkonsumsi Jus Aloe vera adalah 77,80 dengan standart deviasi 7,143, tekanan darah minimum $66 \mathrm{mmHg}$ dan maksimum 90 $\mathrm{mmHg}$.

\section{Kadar Kolesterol Pasien Hiperkolesterolemia SEbELUM DAN SESUdAH MENGKONSUMSI JuS ALOE VERA}

Berdasarkan penelitian yang dilakukan, diperoleh deskriptif kadar kolesterol pasien sebelum dan sesudah mengkonsumsi Jus Aloe vera seperti pada tabel berikut:

Tabel 3. Distribusi FrekUensi Kadar KOLESTEROL SEBELUM DAN SESUDAH Mengkonsumsi Jus aloe Vera di Puskesmas AIR DINGIN TAHUN 2018

\begin{tabular}{lcccc}
\hline $\begin{array}{l}\text { Kadar } \\
\text { Kolesterol }\end{array}$ & Mean & $\begin{array}{c}\text { Std. } \\
\text { Deviasi }\end{array}$ & Min & Maks \\
\hline Sebelum & 264,93 & 82,083 & 203 & 535 \\
Sesudah & 240,26 & 38,257 & 201 & 335 \\
$\alpha$ & 24,67 & 43,826 & 2 & 200 \\
\hline
\end{tabular}

Berdasarkan tabel 3 diperoleh hasil kadar kolesterol sebelum mengkonsumsi Jus Aloe vera diperoleh rata-rata 264,93 dengan standart deviasi 82,083, kadar kolesterol minimum 203 dan maksimum $535 \mathrm{mmHg}$. Kadar kolesterol sesudah mengkonsumsi Jus Aloe vera adalah 240,36 dengan standart deviasi 38,357, tekanan darah terendah 201 dan tertinggi $335 \mathrm{mmHg}$.

\section{B. Analisa Bivariat}

Berdasarkan penelitian yang dilakukan, diperoleh hasil penelitian tentang korelasi perubahan tekanan darah dengan perubahan kadar kolesterol total pada pasien prolanis hiperkolesterolemia yang mendapatkan jus aloe vera di Puskesmas Air Dingin tahun 2018 pada tabel dibawah ini:

\section{Tabel 4. Korelasi Perubahan Tekanan Darah DENGan Perubahan Kadar Kolesterol TOTAL PADA PASIEN HIPERKOLESTEROLEMIA YANG MENDAPATKAN Jus aloe Vera di Puskesmas AIr Dingin TAHUN 2018}

\begin{tabular}{lc}
\hline & Kadar Kolesterol Total \\
\hline Sistolik & $\mathrm{r}=0,875$ \\
& $\mathrm{p}=0,000$ \\
$\mathrm{n}=15$ \\
\hline Diastolik & $\mathrm{r}=0,631$ \\
& $\mathrm{p}=0,012$ \\
& $\mathrm{n}=15$ \\
\hline
\end{tabular}

Berdasarkan tabel 4 hasil uji statistic (spearmen rho) pada tekanan darah sistolik diperoleh nilai $\mathrm{r}=0,875$ dengan kekuatan berada antara 0,80-1,000 kategori sangat kuat, nilai $\mathrm{p}=0,000 \quad(\mathrm{p}<0,05)$ dan pada 
tekanan darah diastolik diperoleh nilai $\mathrm{r}=$ 0,631 berada diantara 0,6-0,799 kuat, nilai $\mathrm{p}=0,012(\mathrm{p}<0,05)$, maka dapat disimpulkan bahwa terdapat korelasi perubahan tekanan darah dengan perubahan kadar kolesterol total pada pasien prolanis dengan gangguan kolesterol yang mendapatkan jus aloe vera di Puskesmas Air Dingin tahun 2018.

\section{Pembahasan}

\section{A. Tekanan Darah Pasien HiPERKOLESTEROLEMIA SEBELUM DAN SESUdAh Mengkonsumsi JuS ALOE VERA}

Berdasarkan penelitian diperoleh hasil tekanan darah sistolik sebelum mengkonsumsi Jus Aloe vera diperoleh ratarata $137,26 \mathrm{mmHg}$ dan sesudah mengkonsumsi Jus Aloe vera menjadi 119,86 $\mathrm{mmHg}$ dan tekanan darah diastolik sebelum mengkonsumsi Jus Aloe vera diperoleh ratarata $86,13 \mathrm{mmHg}$ dan tekanan darah diastolik sesudah mengkonsumsi Jus Aloe vera menjadi $77,80 \mathrm{mmHg}$.

Hasil penelitian ini sejalan dengan penelitian sebelumnya yang dilakukan oleh Shella pada tahun 2016 kepada penderita hipertensi di Pontianak Utara diperoleh hasil rerata tekanan darah sistolik sebelum dilakukan perlakuan adalah $148 \mathrm{mmHg}$ dan sesudah perlakuan 134,50 $\mathrm{mmHg}$ dan tekanan darah diastolik sebelum perlakuan $99 \mathrm{mmHg}$ dan sesudah perlakuan $90 \mathrm{mmHg}$ dan juga penelitian yang dilakukan oleh Wasita pada tahun 2014 kepada lansia penderita hipertensi di Denpasar diperoleh hasil penurunan tekanan darah sistolik menjadi normal dengan rata-rata $131,58 \mathrm{mmHg}$ dan tekanan darah diastolik normal $\quad(<80$ $\mathrm{mmHg}){ }^{13,14}$

Hal ini terkait dengan teori yang dikemukakan oleh Barasai pada tahun 2009 bahwa faktor yang mempengaruhi dalam menurunnya prevalensi penyakit hipertensi pada penderita adalah konsumsi kalium, flavonoid dan arginin yang adekuat atau sesuai dengan rekomendasi yang harus dikonsumsi per hari oleh pasien. Lidah buaya juga memiliki kandungan flavonoid yang menyebabkan efek antihipertensi. Menurut Satria tahun 2009, mekanisme kerja dari flavonoid yaitu melancarkan peredaran darah dan mencegah terjadinya penyumbatan pada pembuluh darah, sehingga darah dapat mengalir dengan normal dan mengurangi kandungan kolesterol serta mengurangi penimbunan lemak pada dinding pembuluh darah. $^{14}$

Teori lain juga menunjukan intervensi terapi jus lidah buaya terhadap orang dengan tekanan darah tinggi memiliki efek menurunkan tekanan darah, baik itu tekanan darah sistolik maupun tekanan darah diatolik. Hal ini dikarenakan beberapa kandungan yang dimiliki daging lidah buaya memiliki efek menurunkan tekanan darah diantaranya adalah flavonoid, arginin dan kalium. Renin dan angiotensin berperan penting dalam pengaturan tekanan darah, oleh karena itu flavonoid yang dimiliki lidah buaya dapat membantu menurunkan tekanan darah dengan cara menghambat Angiotensin Converting Enzyme (ACE) sehingga menghambat terjadinya perubahan angiotensin I menjadi angiotensin II, sehingga mampu menurunkan kadar angiotensin II, apabila kadar angiotensin mengalami penurunan maka akan menyebabkan terjadinya vasodilatasi dari pembuluh darah yang pada akhirnya akan menyebabkan turunnya tekanan darah. ${ }^{13}$

\section{B. Kadar Kolesterol Pasien HIPERKOLESTEROLEMIA SEBELUM Dan Sesudah Mengkonsumsi Jus ALOE VERA}

Berdasarkan penelitian diperoleh hasil kadar kolesterol sebelum mengkonsumsi Jus Aloe vera diperoleh rata-rata 264,93 dengan standart deviasi 82,083 kadar kolesterol minimum 203 dan maksimum $535 \mathrm{mmHg}$. Kadar kolesterol sesudah mengkonsumsi Jus Aloe vera adalah 240,36 dengan standart 
deviasi 38,357, kadar kolesterol terendah 201 $\mathrm{mmHg}$ dan tertinggi $335 \mathrm{mmHg}$.

Hasil penelitian ini sejalan dengan penelitian sebelumnya yang dilakukan oleh Sianipar tahun 2012 diperoleh hasil pada pemberian jus Aloe vera $200 \mathrm{mg}$ menyebabkan penurunan kadar kolesterol LDL dan meningkatkan kadar kolesterol HDL secara bermakna. Kadar kolesterol LDL menurun sebesar 20,36\% dan kadar kolesterol HDL meningkat sebesar $18,87 \%$ setelah diberikan jus lidah buaya selama 14 hari. $^{11}$

Salah satu kandungan lidah buaya yaitu glukomanan, zat yang merupakan serat larut. Glukomanan dapat menurunkan kadar risiko penyakit kardiovaskuler dengan menurunkan kadar lipid didalam plasma melalui mekanisme peningkatan viskositas kandungan intestinal sehingga dapat menurunkan reabsorbsi asam empedu dan memperlambat absorbsi serat, sehingga meningkatkan ekskresi asam empedu dan menurunkan asupan energi secara keseluruhan. ${ }^{11}$

Lidah buaya dapat menurunkan kadar kolesterol LDL secara bermakna karena mengandung glukomanan, anthraquinones, asam folat, enzim lipase, lignin, vitamin B3 dan vitamin C. ${ }^{11}$ Anthraquinones mempercepat transport makanan di usus dan menghambat penyerapan kolesterol. $^{12}$ Vitamin B3 (asam nikotinat) yang mampu menghambat produksi VLDL yang akan menurunkan kadar LDL. ${ }^{12}$ Vitamin $\mathrm{C}$ yang mempunyai efek membantu reaksi hidroksilasi dalam pembentukan asam empedu sehingga meningkatkan produksi garam empedu yang berakibat meningkatnya ekskresi kolesterol.

Lidah buaya juga dapat meningkatkan kadar kolesterol HDL karena lidah buaya mengandung bahan aktif seperti niasin, magnesium, selenium, zinc, dan vitamin $C$. Niasin dapat meningkatkan produksi Apoliporotein A-1 sehingga kadar HDL meningkat. Magnesium dapat meningkatkan produksi Apolipoprotein A-IV dan Apolipoprotein E sehingga HDL kolesterol meningkat. Selenium dan zinc dapat meningkatkan kadar kolesterol HDL dan menurunkan peroksidasi lipid plasma. Vitamin $\mathrm{C}$ dapat meningkatkan kadar kolesterol HDL. Mekanisme vitamin C dalam meningkatkan kadar kolesterol HDL yakni dengan cara meningkatkan mRNA apolipoprotein A-1 hati yang berperan dalam sintesis apolipoprotein A-1 dan meningkatkan kadar apolipoprotein A-1 didalam darah. Apoliporotein A-1 merupakan komponen utama kolesterol HDL. ${ }^{11}$

\section{Korelasi Perubahan Tekanan Darah dengan Perubahan Kadar KOLESTEROL TOTAL}

Berdasarkan penelitian diperoleh hasil uji statistic (spearmen rho) pada tekanan darah sistolik diperoleh nilai $\mathrm{r}=0,875$ kategori sangat kuat, nilai $\mathrm{p}=0,000(\mathrm{p}<0,05)$ dan pada tekanan darah diastolik diperoleh nilai $\mathrm{r}=$ 0,631 kategori kuat, nilai $\mathrm{p}=0,012(\mathrm{p}<0,05)$, maka dapat disimpulkan bahwa terdapat korelasi perubahan tekanan darah dengan perubahan kadar kolesterol total pada pasien prolanis dengan gangguan kolesterol yang mendapatkan jus Aloe vera di Puskesmas Air Dingin tahun 2018.

Hasil penelitian ini sejalan dengan penelitian sebelumnya yang dilakukan oleh Margarita dkk tahun 2013 menemukan hasil yakni terdapat hubungan yang signifikan antara kadar kolesterol total dengan tekanan darah pada orang dewasa. ${ }^{9}$ Hal yang serupa juga ditemukan oleh Tyas dan Catur tahun 2015 didapatkan hubungan yang bermakna secara statistik antara kadar kolesterol total dalam darah dengan tekanan darah sistolik dan diastolik. $^{15}$

Makanan merupakan penyebab penting risiko terbentuknya kadar kolesterol yang tinggi pada darah. Tingginya kadar kolesterol dapat meningkatkan terjadinya 
tekanan darah yang tinggi. Timbunan kolesterol di dalam darah akan mengakibatkan penebalan dinding arteri yang disebabkan oleh plak kolesterol. Ketika dinding-dinding pada pembuluh darah menjadi tebal dan kaku karena tumpukan kolesterol, maka saluran arteri kehilangan kelenturannya dan menjadi kaku. Akibatnya, pembuluh darah tidak dapat mengembang secara elastis saat jantung memompa darah melalui pembuluh darah dan darah didorong dengan kuat untuk dapat melalui pembuluh darah yang sempit tersebut, sehingga menyebabkan kenaikan tekanan darah. ${ }^{16}$

\section{Penutup}

\section{A. Kesimpulan}

Berdasarkan hasil penelitian korelasi perubahan tekanan darah dengan perubahan kadar kolesterol total pada pasien prolanis dengan gangguan kolesterol yang mendapatkan jus Aloe vera di Puskesmas Air Dingin tahun 2018, maka dapat disimpulkan bahwa: terdapat penurunan kadar kolesterol total pada pasien prolanis dengan gangguan kolesterol setelah pemberian jus Aloe vera di Puskesmas Air Dingin tahun 2018. Terdapat penurunan tekanan darah sistolik dan diastolik pada pasien prolanis dengan gangguan kolesterol setelah pemberian jus Aloe vera di Puskesmas Air Dingin tahun 2018. $\quad(\mathrm{p}<0.05) \quad$ Terdapat korelasi yang signifikan perubahan tekanan darah dengan perubahan kadar kolesterol total pada pasien prolanis dengan gangguan kolesterol yang mendapatkan jus aloe vera di Puskesmas Air Dingin tahun 2018.

\section{B. SARAN}

\section{Bagi Puskesmas}

Bagi pihak Puskesmas Air Dingin Padang dapat memberikan tambahan edukasi kesehatan berupa terapi dengan cara mengkonsumsi jus lidah buaya untuk menurunkan kadar kolesterol dan tekanan darah. Sebaiknya bagi pengelolah prolanis agar lebih memperhatikan pemberian edukasi kesehatan berupa penyuluhan yang juga merupakan bagian dari program puskesmas untuk selalu tetap dilaksanakan, karena mengingat masih rendahnya kesadaran masyarakat untuk berperilaku preventif terhadap penyakit.

\section{BAgi MASYARAKat}

Hasil penelitian dapat menjadi bahan pertimbangan bagi masyarakat dalam memilih pengobatan alternatif atau pelengkap dalam pengobatan, yang telah diuji dan praktis dalam menurunkan kadar kolesterol dan terkontrolnya tekanan darah yaitu dengan mengonsumsi jus lidah buaya yang dapat dijadikan tanaman obat dirumah.

\section{Bagi Peneliti Selanjutnya}

Bagi peneliti selanjutnya agar dapat melakukan penelitian lebih lanjut mengenai penggunaan pengobatan herbal atau jus buah lainya yang efektif untuk menurunkan hipertensi dan kadar kolesterol sehingga bisa dijadikan sebagai obat alternative pengganti obat.

\section{Daftar Pustaka}

[1] Rosdiana AI, Raharjo BB, Indarjo S. Implementasi Program Pengelolaan Penyakit Kronis (Prolanis). Higeia J Public Heal Res Dev. 2017;1(3):140-150.

http://journal.unnes.ac.id/sju/index.php/higeia.

[2] Herningtyas $\mathrm{EH}, \mathrm{Ng}$ TS. Prevalence and distribution of metabolic syndrome and its components among provinces and ethnic groups in Indonesia. BMC Public Health. 2019;19(1):112.

[3] Suhaema, Masthalina H. Pola Konsumsi Dengan Terjadinya Sindrom Metabolik di Indonesia. $J$ Kesehat Masy Nas. 2015;9(4):340-347.

[4] Biro Komunikasi dan Pelayanan Masyarakat KKR. Hipertensi Penyakit Paling Banyak Diidap Masyarakat. 2019

[5] Dinas Kesehatan Provinsi Sumatra Barat. Profil Dinas Kesehatan Sumatera Barat Tahun 2017. 2017:1-145.

[6] Dinas Kesehatan Kota Padang. Profil Kesehatan Kota Padang Tahun 2018. Dinas Kesehat Kota Padang. 2018;(45):1-169.

[7] Maryati H. Hubungan Kadar Kolesterol Dengan Tekanan Darah Penderita Hipertensi Di Dusun Sidomulyo Desa Rejoagung Kecamatan Ploso Kabupaten Jombang. 2017; 8: 1-10. http://ejournal.umm.ac.id/index.php/keperawatan /issue/view. 
[8] Harefa MV, Rasmaliah, Jemadi. Hubungan Kadar Kolesterol dengan Derajat Hipertensi pada Penderita Hipertensi di Wilayah Kerja Puskesmas Hiliweto Gido, Kabupaten Nias. 2017:1-6.

[9] Margarita Y, Andi P, Erwina M, et al. Kadar Kolesterol Total dan Tekanan Darah Orang Dewasa Indonesia. Artik Penelit. 2015;3(1):5056.

[10] Lestari TW. Hubungan Kadar Kolesterol dengan Tekanan Darah pada Pra Lansia Hipertensi di Posyandu Lansia Dusun Jetis Bantul Yogyakarta. PhD Propos. 2015;1(c):29-32.

[11] Sianipar Y. Pengaruh Pemberian Jus Lidah Buaya (Aloe vera) Terhadap Kadar Kolesterol Low Density Lipoprotein (LDL) Dan High Density Lipoprotein (HDL). Vol 1.; 2012.

[12] Prakoso Z. Pengaruh Pemberian Vitamin C Terhadap Kadar LDL dan HDL Kolesterol Serum Tikus Wistar Jantan Hiperlipidemia Setelah Perlakuan Jus Lidah Buaya (Aloe vera Linn). Article. 2006;68(16):16.

[13] Ramadhani S. Pengaruh Jus Lidah Buaya (Aloe vera Chinensis) Terhadap Tekanan Darah Pada Penderita Hipertensi Di Wilayah Kerja Upk Puskesmas Khatulistiwa Kecamatan Pontianak Utara. 2016.

[14] Wasita, RRR., Gunaharianti N. Pengaruh Pemberian Jus Lidah Buaya (Aloe vera) Dan Jus Belimbing (Averrhoa Carambola L.) Terhadap Penurunan Tekanan Darah Pada Lansia Penderita Hipertensi Di Panti Sosial Tresna Werdha (PSTW) Wana Seraya Denpasar. 2015:1-7.

[15] Naue SH, Doda V, Wungouw H. Hubungan kadar kolesterol total dengan tekanan darah pada guru di SMP $1 \& 2$ Eben Haezar dan SMA Eben Haezar Manado. J e-Biomedik. 2016;4(2):1-7.

[16] Harefa, Vania M. Hubungan Kadar Kolesterol Dengan Derajat Hipertensi Pada Penderita Hipertensi di Wilayah Kerja Puskesmas Holiweto Gido, Kabupaten Nias. 2017;49. 